\section{Safety in the laboratory}

\author{
W A Telfer Brunton
}

\section{Introduction}

Safety in the workplace has been an important industrial relations issue since the industrial revolution. Currently, legislation in the United Kingdom is based on the 1974 Health and Safety at Work Act. ${ }^{1}$ This legislation places clear responsibilities both on employers and employees. However, it was not until the publication of the Code of Practice for the Prevention of Infection in Clinical Laboratories and Post-mortem Rooms ("Howie Report") in 1978, that the problem of occupationally acquired infections and the containment of infectious agents in pathology departments was adequately addressed. Although widely criticised at first, much of the guidance contained in that report is now considered standard laboratory practice.

During the 1980s guidance on many aspects of laboratory safety has been published and the successor to the Howie code, now in three volumes, ${ }^{2-4}$ attempts to bring together some of the information contained within them. Although some may be disappointed with the contents, they provide a sensible framework for good practice.

(F Clin Pathol 1992;45:949-951)

\section{Safety and the organisation}

If good safety standards are to be achieved in an organisation, safety must be taken seriously at all levels of management and by employees. If management do not take it seriously then they cannot expect employees to do so either. In the National Health Service the local responsibility for safety in laboratories rests with the heads of departments, although the day-to-day management of safety issues and audit may be delegated to a named safety supervisor or officer.

A departmental safety committee should be set up and may be an official subcommittee of the employer's statutory safety committee. This should meet regularly, three or six monthly, and, if they request it, trade union representatives may attend. These meetings should be used to discuss the findings of safety audits, to examine accident and incident reports and to provide a regular means of communication between employer and employees. It should also be instrumental in producing and approving policies and emergency plans.

The basis of good safety practice is hazard analysis or risk assessment. Only when risks and dangers have been identified can suitable practices be devised to minimise risk to staff and the environment. This principle forms the basis of most new safety legislation and guidance, for example, the Control of Substances Hazardous to Health (COSHH) Regulations, $1988^{56}$ and the Guidance for Clinical Health Care Workers: Protection Against Infection with HIV and Hepatitis Viruses. ${ }^{\text {? }}$

\section{Safety policies}

Every laboratory must have its own safety manual. It is not adequate just to refer staff to national guidance and hope for the best. All staff must be given a copy of the manual and should give written confirmation that they have read it, although this does not reduce the employer's responsibility to provide adequate safety training.

A safety manual must meet the individual range of risks present in a given department and must include model rules for all staff working in the department, including porters, cleaners, phlebotomists, visitors and engineers. Clear guidance must be provided for handling spillages, contamination of the environment, and the safe use and disposal of waste, including sharps.

\section{Training}

All staff must be trained sufficiently to cope with the hazards of their job and to understand the safety precautions required to protect them from occupationally acquired infection. Working practices should be defined in written laboratory methods. High technical standards are central to achieving safe practice. Safety training may be an integral part of the general training of staff or in some cases-for example, fire training or radiation protection-special sessions or courses may be required. All pathology laboratories should have some staff trained in First Aid.

\section{Safety supervisors}

Safety supervisors or officers in pathology departments are key people; they need to be relatively senior members of the laboratory staff and require special training. They will generally be responsible for maintaining safety standards throughout the department and, with heads of departments, for preparing written safety policies. They will also carry out regular safety audits, take responsibility for liaison with local fire officers, radiation protec- 
tion officers, etc, and perform initial and continuing risk assessments under $\mathrm{COSHH}$ and other relevant regulations. All hazard warning notices and other safety information must be made available to them.

\section{Occupational health}

An effective occupational health scheme must exist. This may be contracted to a local occupational health department, but it is vital that all heads of departments seek regular confirmation that their policies for immunisation, $x$-ray pictures, etc, are being implemented. All staff working with specimens in pathology departments should be offered hepatitis $B$ vaccine and other immunisations as considered appropriate. Employers may wish to issue medical contact cards to their employees, and a list of general practitioners should be maintained and regularly updated.

\section{Premises}

It is impossible to maintain good safety standards in inadequate premises. Laboratory design is highly specialised and the users must be intimately involved in the design of new facilities. New premises are not always satisfactory and even in modern laboratories, category 3 rooms with unsealed suspended ceilings, which make fumigation impossible in the event of a disaster, are common. Safety cabinets need to be sited properly within containment suites and the ventilation of the laboratory as a whole has an important effect on working conditions.

Proper security arrangements must be made to prevent access by the public to laboratory areas and appropriate hazard warning notices must be displayed. The safety of staff working out of hours must be carefully considered.

The new guidance concerning the design of postmortem rooms, in particular their ventilation, facilities for organ and body storage, and for viewing may have substantial implications for health care providers. ${ }^{3}$

\section{Equipment}

The perception of risk has changed since the publication of the Howie code and especially since the advent of human immunodeficiency virus infection. Equipment has developed rapidly to cope with these risks, but the evaluation of all new pieces of equipment should include their safety and ease of disinfection. All equipment must be kept clean and regularly decontaminated, and for centrifuges it is now recommended that this must be done at least daily. Regular maintenance and servicing of equipment is important and where necessary disinfection must be performed before the engineer begins work. Log books and performance checks on autoclaves and exhaust protective cabinets must be routinely checked by the safety supervisor and any problems dealt with as a matter of priority.

The electrical safety of both the premises and equipment must be checked regularly ${ }^{8}$ and heads of departments should receive written reports of the results of these checks.

\section{Protective clothing}

Appropriate protective clothing must be worn by all laboratory workers. The precise nature of this clothing will depend on the task being performed and the level of containment required to perform the work safely. ${ }^{9}$ Laboratory workers should wear side fastening coats to protect their clothes in the event of accidents, and for some activities, for example, handling hazardous fluid, wearing gloves and a plastic apron will be desirable. Those separating blood specimens should wear a face visor or spectacles.

The debate about suitable gloves for those performing postmortem examinations remains unresolved. For very high risk activities steel mesh gloves may be required but they are clumsy and hamper the performance of the necropsy. Hopefully some of the experimental gloves being developed will prove more acceptable for this purpose.

\section{Radiation, chemicals and waste}

The Control of Substances Hazardous to Health (COSHH) Regulations ${ }^{56}$ require employers to assess risk and to comply with certain safety standards for the use and disposal of dangerous substances. Employers are required to identify and indeed anticipate hazards and to institute appropriate measures to protect their employees. Regular monitoring of levels may be required for some substances-for example, glutaraldehyde, and extract cabinets may be required to reduce exposure of staff to toxic fumes or powders. Many laboratories also use radioactive substances and fall within the provisions of the Ionising Radiations Regulations, $1985 .^{10}$

In addition, there are strict regulations for the disposal of clinical waste- new guidance in press. All laboratory material from microbiology departments must be made safe either by incineration or autoclaving. Where this cannot be achieved on site, a suitably trained member of staff must supervise the disposal.

\section{Genetic engineering}

Under the Genetic Manipulation Regulations, $1989,{ }^{11}$ it is illegal to perform an activity involving genetic manipulation without notifying the Health and Safety Executive and specifying the nature of the work to be performed. All subsequent significant changes must also be notified.

\section{Specimens and transport}

The labelling, transport, and reception of specimens is an area of continuing difficulty to laboratories as they are not in complete control of their customers' activities. Local policies must be prepared and include suitable arrangements to cover transport within hospital premises, between hospitals by courier or hospital 
vans, and also by taxi. Suitable secondary containers must be provided and arrangements made for their disinfection in the event of accidents. ${ }^{12}$ Pathological material, which must be sent by post, particularly if it may contain any infectious agent, is subject to national or international postal regulations and new European Community standards are in preparation.

\section{Accommodation for "high risk" work}

All diagnostic laboratory work must be performed in accommodation of at least category 2 standard, as defined by the Advisory Committee on Dangerous Pathogens. ${ }^{9}$ All hospital laboratories need to have access to a category 3 containment facility, but work on material believed to contain category 4 pathogens may only be performed in a few specialised centres.

Category 3 accommodation and procedures are often inadequate and managers must be pressed to provide resources to remedy defects.

As inoculation is the main risk to laboratory workers performing routine diagnostic work on material which may contain HIV or hepatitis B viruses, an exhaust protective cabinet is not required. A specially designated area of the laboratory or a separate room should, however, be set aside for this purpose. As the incidence of HIV infection increases and as inoculation risk specimens are often not identified, laboratories will need to consider all specimens as being potentially hazardous and adopt suitable practices throughout. Eye protection should be provided for those working with blood or body fluids.

\section{Conclusion}

Achieving a safe environment in laboratories and postmortem examination rooms may seem arduous but is largely a matter of planning, organisation, training and common sense.
New legislation, new pathogens, the increased awareness of environmental issues and our involvement in Europe demand that we take safety issues seriously. As our own health care system changes we may learn from our European colleagues some of the problems of running a "cost per item" pathology service and we must hope that active participation by pathologists in the European Community's activities will allow us to blend the best of our own practices with the best practices of our European partners.

1 Health and Safety at Work, etc. Act 1974. London: HMSO, 1974. ISBN 0105437743

2 Health Services Advisory Committee. Safety in Health Service Laboratories. Safe working and the prevention of infection in clinical laboratories. London: HMSO 1991. ISBN 0118854461 .

3 Health Services Advisory Committee. Safety in Health Service Laboratories. Safe working and the prevention of infection in the mortuary and post-mortem room. London: infection in the mortuary and post-morten
HMSO, 1991. ISBN 0118854488.

4 Health Services Advisory Committee. Safety in Health Service Laboratories. Safe working and the prevention of infection in clinical laboratories-model rules for staff and infection in clinical laboratories-model rules for staff and visitors. London: HMSO,

5 Health and Safety Commission. Control of Substances Hazardous to Health Regulations, 1988. Control of substances hazardous to health (General ACoP) and Control of carcinogenic substances (Carcinogens ACoP). Approved Code of Practice. London: HMSO, 1988. ISBN 0118854682.

6 Health and Safety Commission. Control of Substances Hazardous to Health Regulations, 1988. Control of substances hazardous to health in fumigation operations. Approved Code of Practice. London: HMSO, 1988. ISBN 011885469 0 .

7 DSS. Guidance for Clinical Health Care Workers: Protection mendations of the Expert Advisory Group on AIDS. UK mendations of the Expert Advisory Group on AIDS. UK 3212496 .

8 Health and Safety Executive. Memorandum of guidance on the Electricity at Work Regulations 1989. Health and safety series booklet $H S(R) 25$. London: HMSO, 1989. ISBN 0 118839632.

9 Advisory Committee on Dangerous Pathogens. Categorisation of pathogens according to hazard and categories of containment. Second ed. 1990. London: HMSO, 1990. ISBN 0118855646.

10 The protection of persons against radiation arising from any work activity. The Ionising Radiations Regulations 1985. Approved Code of Practice. London: HMSO, 1985. ISBN 011 Code of $P 838385$.

11 Health and Safety Executive. Genetic Manipulation Regulations 1989. Guidance on regulations. London: HMSO, 1989. ISBN 0118855131

12 Health Service Advisory Committee. Safety in health service laboratories: the labelling and transport of specimens. London: HMSO, 1986. ISBN 0118838938. 